\title{
The Agenda of British Government: The Speech from the Throne, 1911-2008
}

\author{
Will Jennings, Shaun Bevan and Peter John \\ University of Manchester
}

\begin{abstract}
This article considers how UK governments use the Speech from the Throne (also known as the Gracious Speech and the King's or the Queen's Speech) to define and articulate their executive and legislative agenda. The analysis uses the policy content coding system of the Policy Agendas Project to measure total executive and legislative attention to particular issues. This generates the longest known data series of the political agenda in the UK, from the date of the first Parliament Act in 1911 right up to the end of 2008, nearly a century of government agenda setting. Using these data, the article identifies long-run institutional and policy stability in this agenda-setting instrument, and variation in its length and executive-legislative content due to the focusing events of world wars and party control of government. It assesses the degree to which the policy content of the speech is persistent (autoregressive) over time and identifies long-term trends in the total number of topics mentioned in each speech (scope), and the dispersion of government attention across topics (entropy). It also identifies important variation over time that indicates change in the agenda-setting function of the speech and evolution of the agenda in response to policy challenges faced by modern British governments in the period since 1911. Overall, the analysis demonstrates the robustness of the speech as a measure of the policy agenda and executive priorities in the UK.
\end{abstract}

\begin{abstract}
Agenda:
'... the list of subjects or problems to which governmental officials, and people outside of government closely associated with those officials, are paying some serious attention at any given time' (Kingdon, 1984, p. 3).
\end{abstract}

\section{Agenda Setting in British Politics}

At any moment in time, government faces an abundance of information about the state of the world as issues compete for space on the political agenda (Carmines and Stimson, 1989; Jones and Baumgartner, 2005; True et al., 2007). Such information ranges from domestic policy to international affairs - on topics such as the economy, education, immigration, public services, defence, crime and climate change. This array of issues requires processing, prioritisation and action as elected officials attempt to make sense of and respond to electoral mandates and the demands of political parties, bureaucrats, interest groups, public opinion and the media. The critical questions for the study of agenda setting (see the seminal studies of Baumgartner and Jones, 1993; Cobb and Elder, 1983; Kingdon, 1984; McCombs and Shaw, 1972) are how and why a particular issue is elevated on to the political agenda ahead of other issues.

Not much is known about agenda setting in British politics. Indeed, systematic analysis of the agenda of executive government is rare in comparison to studies of issue competition 
by political parties during election periods (e.g. Budge and Hofferbert, 1992; Budge et al., 2001; Klingemann et al., 1994; McDonald and Budge, 2005). Recent studies, however, consider dynamics of political attention in Britain (Jennings and John, 2009; John and Jennings, 2010) while others undertake comparative analysis of executive agendas, focusing on issue stability (Breeman et al., 2009a; 2009b), opinion responsiveness (Hobolt and Klemmensen, 2005) and issue diversity (Jennings et al., 2009). The agenda of executive government matters both because incumbents tend to be the focus of the media and public agendas, and because the policy priorities of government are integral to political competition outside election campaigns. It also matters because the day-to-day business of government necessitates rapid responses to problems and demands from the external world. Climate change, the credit crunch and pension deficits are all examples of problems thrust on to the agenda through no direct choice of governments or political parties. Elections and parties matter, but events matter too.

With this multitude of pressures and problems, the executive needs to explain how it intends to allocate its precious time and resources to respond to them - through either executive or legislative action. Such an expression of the executive agenda can be aimed at a number of different audiences - ranging from members of parliament to government departments, the grass-roots membership of the governing party, the media and the public in general. The annual executive speech is a measure of such attention, providing a window into the nature of executive politics and policy making. This is a platform through which government aims to set the national agenda, outlining general priorities and specifying proposals for parliamentary debate and enactment. The speech is one of the many agendasetting institutions of British government, such as budgets or Acts of Parliament. This article therefore seeks to improve understanding of the Speech from the Throne, a prominent formal signal of the executive agenda and a long-standing means of setting the agenda. In particular, what differences are there in the composition of the speech and its use by different governments over time and what aspects of the speech have remained relatively stable over the last hundred sessions of parliament?

Why does the study of the executive's priorities matter? Over the past couple of decades, much of modern British political analysis has become preoccupied with the claim that power has become fragmented from the centre, with the hollowing out of the core executive and the rise of networked governance (e.g. Bevir and Rhodes, 2003; Rhodes, 1997). However, such accounts remain silent on the influence that the executive retains through its ability to set the national agenda and fix the terms of debate - through its prioritisation of problems, the creation of institutional structures and definition of issues. The presidentialisation of British politics (e.g. Foley, 1993) highlights the specific power of the prime minister and the core executive to set the agenda despite this shift from government to governance. E. E. Schattschneider (1960, p. 68) argues that 'the definition of alternatives is the supreme instrument of power', meaning that the framing of an issue determines its mobilisation of support. Theories of agenda setting and issue evolution are essential to understanding processes of political change in the US (e.g. Baumgartner and Jones, 1993; Carmines and Stimson, 1989; Kingdon, 1984). There is a lacuna, then, in the British context regarding the agenda of executive government - expressed through 
institutions such as the Speech from the Throne - and the degree to which it has remained stable despite erosion of the institutions of central government and abdication of its powers. The analysis here presents empirical data from the UK Policy Agendas Project (www.policyagendas.org.uk) on the agenda of British government, generated through systematic coding of policy content in agendas such as the Speech from the Throne, Acts of Parliament, budgets, media and public opinion. This coding system is adapted from the original US Policy Agendas Project (see Baumgartner et al., 1998; www.policyagendas. org), enabling analysis with other countries that have also implemented this approach (www.comparativeagendas.org).

\section{The Speech from the Throne}

The Speech from the Throne - also known as the Gracious Speech and the King's or the Queen's Speech - is an integral feature of the State Opening of Parliament when the sovereign addresses the chamber of the House of Lords with members of the House of Commons watching from the galleries. This institutionalised ritual is characteristic of what Bagehot (1872) described as the dignified part of the British constitution, in which political custom and tradition perform a stabilising function in contrast to its functional efficient aspects. Such a convention in which the head of government or the head of state delivers a formal annual statement, on behalf of the executive, setting out its priorities for the year ahead is found across a range of political systems. In countries such as Canada, Denmark, France, the Netherlands, Spain and the US this summarises issues or policies that are of interest to government, including legislative proposals and executive priorities (e.g. Breeman et al., 2009a; 2009b; Cohen, 1995; 1997; Hobolt and Klemmensen, 2005; 2008; Jennings and John, 2009; Jennings et al., 2009). ${ }^{1}$ Since 1901, the Speech from the Throne has been a permanent fixture of the political calendar in Westminster, occurring at the start of the parliamentary session. ${ }^{2}$ The speech highlights matters of importance to the government and details the legislative programme that government intends to enact in the forthcoming year. By highlighting certain issues and ignoring others, this provides an annual platform for government to shape the national agenda.

The unification of executive and legislative powers in the British political system, combined with its long-standing tradition of party discipline, suggests that there should be a close link between executive and legislative agendas and the other outputs of government. Empirical evidence shows a strong relationship between manifesto pledges, legislative proposals of governing parties and actual policy outputs (Bara, 2005). While there is no formal bargaining between the executive and the legislature, unlike in the US (Groseclose and McCarty, 2001), there may be some kind of implicit negotiation between the executive and membership of the governing party. The speech might act as a form of credible commitment (North and Weingast, 1989) forcing the governing party to stay the course, to do what it believes is right in the longer term. Such an institution also enables government to 'go public' (Canes-Wrone, 2001; 2005; Kernell, 1997) either to set the tone of national debate over a particular issue or to highlight promises that it intends later to claim credit for keeping (Bara, 2005; Strøm, 2000; 2001). Studies show that despite the separation of powers in the US, presidents can influence the Congressional agenda through public appeals and 
through the annual State of the Union address, the American equivalent of the Speech from the Throne (see Canes-Wrone, 2005; Rudalevige, 2002). Such effects should, in theory, be stronger under the unified executive and legislative powers of the British political system. The speech provides an annual snapshot of executive priorities, as well as an indication of its commitment to specific legislative proposals. Despite being an agenda-setting institution of the executive, it integrates both the executive and legislative priorities of the prime minister.

The speech has been used in analysis as a measure of policy making (Bara, 2005; Hobolt and Klemmensen, 2005; 2008; Jennings and John, 2009; John and Jennings, 2010) and historical political-cultural dynamics (Namenwirth and Weber, 1987), as well as in comparison with similar annual executive speeches delivered by the head of state or head of government in a number of different countries across Western Europe and in the US (Breeman et al., 2009b; Jennings et al., 2009). This statement of the government's agenda is part of the agenda-setting process in British politics. Analysis of its content provides a means for assessing the institutional function of the speech as a signal of executive priorities and legislative proposals.

This analysis explores two aspects of the Speech from the Throne: institutional and policy stability/responsiveness. First, it examines the character of the speech as an agenda-setting institution: in particular through persistence or variation in its format, length and executive-legislative balance over time. Second, it applies the policy content coding system of the Policy Agendas Project to consider persistence in content of the agenda over time, differences in its attention to specific topics, and overall scope and diversity of attention of the executive in its parallel processing of multiple issues at a time. Across both aspects of the speech, it considers responsiveness of the institution and its policy content to partisan control of government and its reaction to exogenous information or system-level shocks.

\section{Research Questions}

The priorities highlighted in the Speech from the Throne are: the product of negotiation within government; parliamentary convention; persistence in the institutional format and policy content of the speech; its emphasis on executive and legislative priorities; partisan differences in use of the speech by governing parties; responsiveness of the executive to events and information about the state of the world; and the relative dispersion of government attention across topics. Each of these questions about the general character of the speech is outlined below, and considered with regard to the institutional and policy aspects of the speech in subsequent analysis. These do not relate to the wider role of the speech in macro-politics or its interaction with other arenas of agenda setting. The aim of the analysis is to advance understanding of the institution of the Speech from the Throne, and measure the persistence of its policy content and its responsiveness to external events and partisan control of government, and the diversity of executive attention over time. Previous research (John and Jennings, 2010) uses these data on the Speech from the Throne for the period between 1940 and 2005. It tested for non-normal distributions of attention 
change to demonstrate the coexistence of stability and punctuations in the executive agenda, a characteristic of the government agenda that is not considered here. The following section provides a brief outline of the five research questions considered in this analysis.

The first research question $\left(Q_{1}\right)$ concerns the relative stability and persistence of the Speech from the Throne over time. As was noted earlier, the speech is a long-standing feature of the British political process and its function in emphasising executive priorities and detailing legislative proposals has remained intact. Alongside the historical stability of this political institution, some studies conclude that the decision-making agenda of government is stable and incremental in character (Richardson and Jordan, 1979; Rose and Davies, 1994). The content of the executive agenda might therefore also be expected to exhibit a degree of persistence in attention to particular issues, even in the presence of punctuated equilibria (Baumgartner and Jones, 1993). Second, in light of the unification of powers in the British system, the speech is a vehicle for prime ministers to express their executive and legislative priorities. It is therefore possible that governments might emphasise their priorities through these alternative powers $\left(Q_{2}\right)$. The third possible dimension of the Speech from the Throne is its potential for selective emphasis or issue ownership (Budge and Farlie, 1983; Carmines and Stimson, 1989; Petrocik, 1996), through which governing parties promote issues that benefit them (Budge and Farlie, 1983) and upon which they enjoy ownership (Petrocik, 1996). Such a model (Q $\left.{ }_{3}\right)$ implies that parties are selective in attention to certain issues at the expense of others, and might be expected to generate a partisan pattern of agenda setting. This contrasts with research suggesting that parties did not make much of a difference to the policies and outputs of British post-war governments (Rose, 1980). The question of interest here, then, is the degree to which content of the Speech from the Throne exhibits systematic differences between parties in government.

The fourth possible institutional function of the executive agenda is its (attention-driven) processing of exogenous information or system-level shocks, such as world wars or constitutional crises $\left(\mathrm{Q}_{4}\right)$. Bryan Jones and Frank Baumgartner (2005) term this process issue intrusion as policy makers incorporate new information about the state of the world into their decisions. While individual issue areas such as health or the environment might respond to changes in public opinion (e.g. Jennings and John, 2009) or media attention, the executive-legislative balance of the speech and its overall dispersion of attention across policy topics should only change in response to events that have a fundamental impact upon the priorities of executive government rather than on single issues.

Lastly, the overall spread of attention across policy topics is an important aspect of the executive agenda and its parallel processing of multiple issues at a time (see True et al., 2007). There is evidence that the issue diversity of executive speeches is a function of government attention to core topics such as the economy, defence and international affairs (Jennings et al., 2009), which either creates or restricts the space available for other issues on the agenda. However, there is also evidence that party manifestos have become more complex in their issue content over time (Green-Pedersen, 2007), with decreasing 
attention to traditional left-right issues. While policy content of the executive agenda is expected to respond to exogenous information or system-level shocks, it is also expected to exhibit increased issue diversity $\left(\mathrm{Q}_{5}\right)$ due to the decline of cleavage-based politics (e.g. Franklin et al., 1992). These five guiding questions are summarised as expectations below.

$\mathrm{Q}_{1}$ : Parliamentary convention means that the format of the Speech from the Throne is stable over time.

$\mathrm{Q}_{2}$ : The Speech from the Throne emphasises distinct executive and legislative priorities.

$\mathrm{Q}_{3}$ : Selective emphasis by governing parties leads to partisan differences in the content of the Speech from the Throne.

$\mathrm{Q}_{4}$ : The Speech from the Throne exhibits issue intrusion through its response to exogenous information or system-level shocks.

$\mathrm{Q}_{5}$ : There is increasing issue diversity in the policy content of the Speech of the Throne.

These five research questions provide a starting point for analysis of the agenda-setting properties of the Speech from the Throne. The inquiry that follows seeks to understand better the form and content of the executive and legislative agenda of British government.

\section{Institutional Stability of the Speech from the Throne}

It is testament to the enduring institution of the Speech from the Throne that the text of the speech has remained so consistent in terms of its format, length and political function throughout the past century. Some of its ceremonial flourishes remain almost unchanged, such as references to the laying down of estimates for public services and the closing refrain from the monarch to members of Parliament: 'I pray that the blessing of Almighty God may rest upon your counsels'. This stability is sustained despite quite dramatic changes in the institutions and policies of British government and the ongoing modernisation of both the language and technologies of public policy making and public administration. Because the format of the Speech from the Throne is so consistent over time it provides a robust measure of attention of British government throughout the ages and for different governing political parties.

How stable is the length of the speech over time? For the period between 1911 and 2008 , its average length was 44 sentences or 1,633 words (see Table 1). The standard deviations for the number of sentences (15.98) and words (558.24) are high, indicating

Table 1: Sentence and Word Summary Statistics (Excluding Special Short Sessions)

\begin{tabular}{lccccc}
\hline & Sentences & Quasi-sentences & Words & Leg-words & Exec-words \\
\hline Mean & 43.99 & 65.07 & 1632.63 & 992.50 & 640.13 \\
SD & 15.98 & 23.45 & 558.24 & 458.01 & 228.72 \\
Min & 9 & 11 & 256 & 73 & 160 \\
Max & 92 & 115 & 3074 & 2108 & 1095 \\
\hline
\end{tabular}


some variation in the observed values. This is evident in Figure 1, which plots the total number of words and sentences in the Speech from the Throne for the period between 1911, the year of the first Parliament Act, and 2008. The length of the speech fluctuates somewhat and appears higher in the post-war era. There are a number of minor shocks, such as the tendency of the length of the speech to fall during wartime and very short speeches for the temporary reopening of parliament from recess for special legislative purposes. Over this period, there were three special short sessions of parliament: in 1921 and 1922 concerning independence of the Irish Free State and in 1948 concerning passage of the third Parliament Act to resolve the gridlock between the House of Lords and the House of Commons. These special short sessions were an opening of parliament for a specific purpose, rather than for a full session of parliament. The ratio between the number of sentences and text characters (plotted in Figure 1) is also quite stable, suggesting that modern governments have not dramatically modified the style of the Speech from the Throne to adapt it to the world of spin and sound bites - which might otherwise have been observed in stability of the number of sentences but a decline in the number of characters as the language became less complex. There has not been a special short session of parliament since 1948. Of course, modernisation of both the language and tools of public policy means that the content of the speech from 1911 is quite distinct when compared to that from 2008. Nevertheless, in each instance the speech carries out the same function in highlighting matters of importance and detailing the legislative programme the government intends to enact in the forthcoming year.

Figure 1: Number of Sentences and Characters in the Speech from the Throne

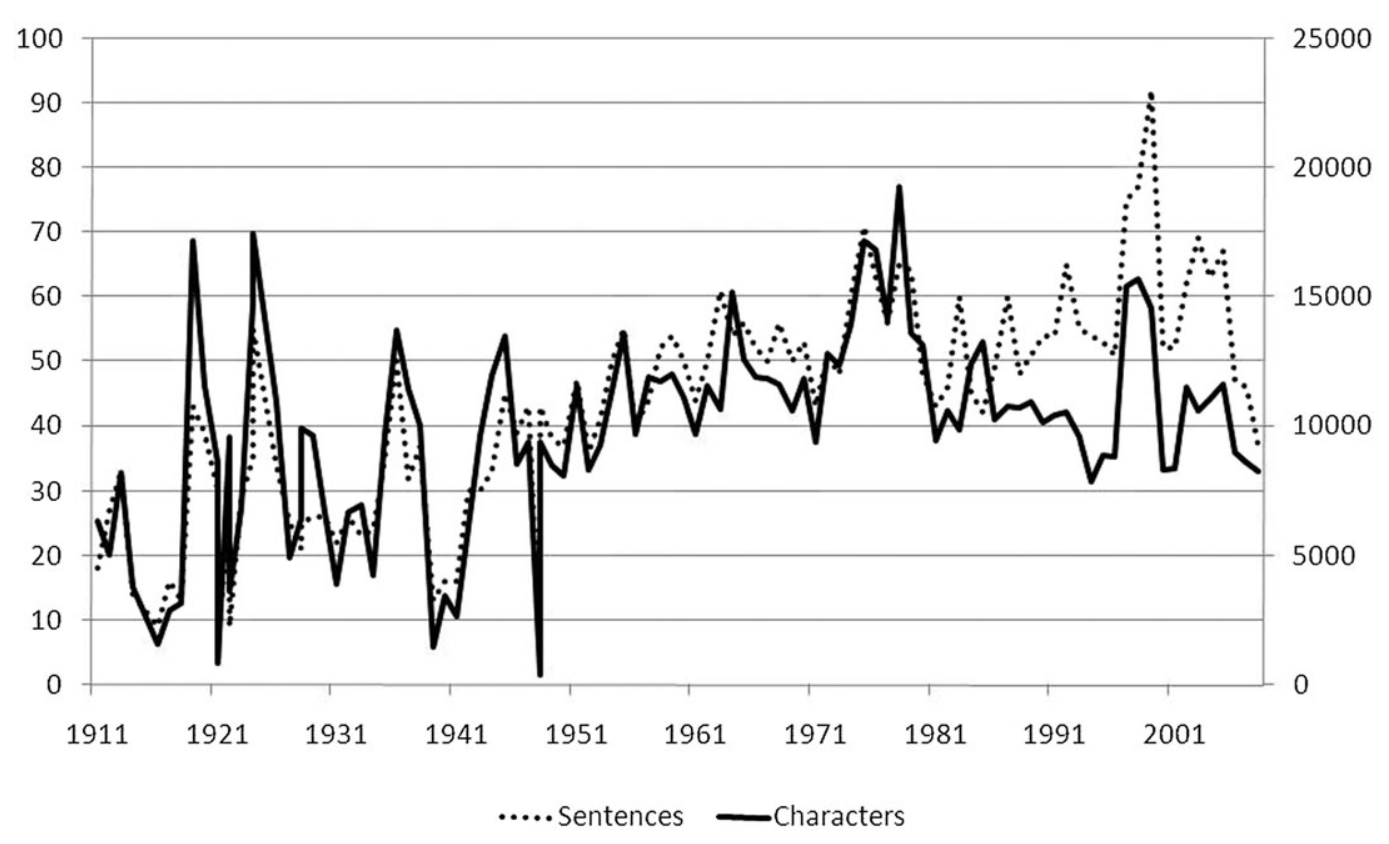




\section{Executive and Legislative Priorities in the Speech from the Throne}

The Speech from the Throne consists of executive and legislative priorities that are delivered as separate parts of the speech. The former consists of a series of statements about matters of executive interest or concern - such as foreign affairs, economic stability and defence along with occasional references to state visits. ${ }^{3}$ Occasionally the executive priorities in the speech refer to other policy areas but these mentions tend to be quite general in nature, such as concerns over the state of the world economy. For example, in the speech of October 1974 the Queen stated: 'My Government will give their full support to international efforts to solve the world-wide problem of inflation and will play a full part in international discussions to solve the problems created by higher oil prices'. The legislative section of the speech communicates specific details of the programme of bills that the government intends to enact during the forthcoming session of parliament. In the same speech of 1974, it was stated: 'Measures will be placed before you to amend the Trade Union and Labour Relations Act 1974; and to establish the Conciliation and Arbitration Service on a statutory basis and to protect and improve working conditions generally'. The executive and legislative sections of the speech are therefore distinguishable from the format and the content of the text. The statistics reported in Table 1 indicate that the length of the legislative section (992.5 words) is, on average, longer than the executive section (640.1 words), reflecting the more substantive function of that part of the speech. ${ }^{4}$ The variation in size of the length of the executive and legislative agenda over time is illustrated in Figure 2.

One noticeable change in format of the Speech from the Throne has been the change in order of the executive and legislative sections of the speech under New Labour. In its historic form, the speech opened with a series of statements about executive priorities before summarising the legislative programme for the forthcoming parliamentary session. The break between the executive and legislative parts of the speech was in most instances distinguishable from the following statement about budgetary appropriations for government:

Members of the House of Commons,

Estimates for the public services will be laid before you.

My Lords and Members of the House of Commons, ...

At a certain point in the speech the government used this statement to indicate a switch from executive to legislative priorities. When Labour came to power in 1997, it reversed the order of the speech - starting with details of the legislative measures it intended to put to parliament, and then proceeding to talk about more general executive priorities and concerns. In practice this means that specific details of government's legislative intentions were highlighted first, perhaps emphasising its fulfilment of manifesto pledges or other executive promises. This would be consistent with New Labour's emphasis upon both targets and benchmarks (see Hood, 2006), such as in its programme of Public Service Agreements. This change has no detectable impact upon policy content of the speech but 
Figure 2: Size of the Executive and Legislative Agenda (Words)

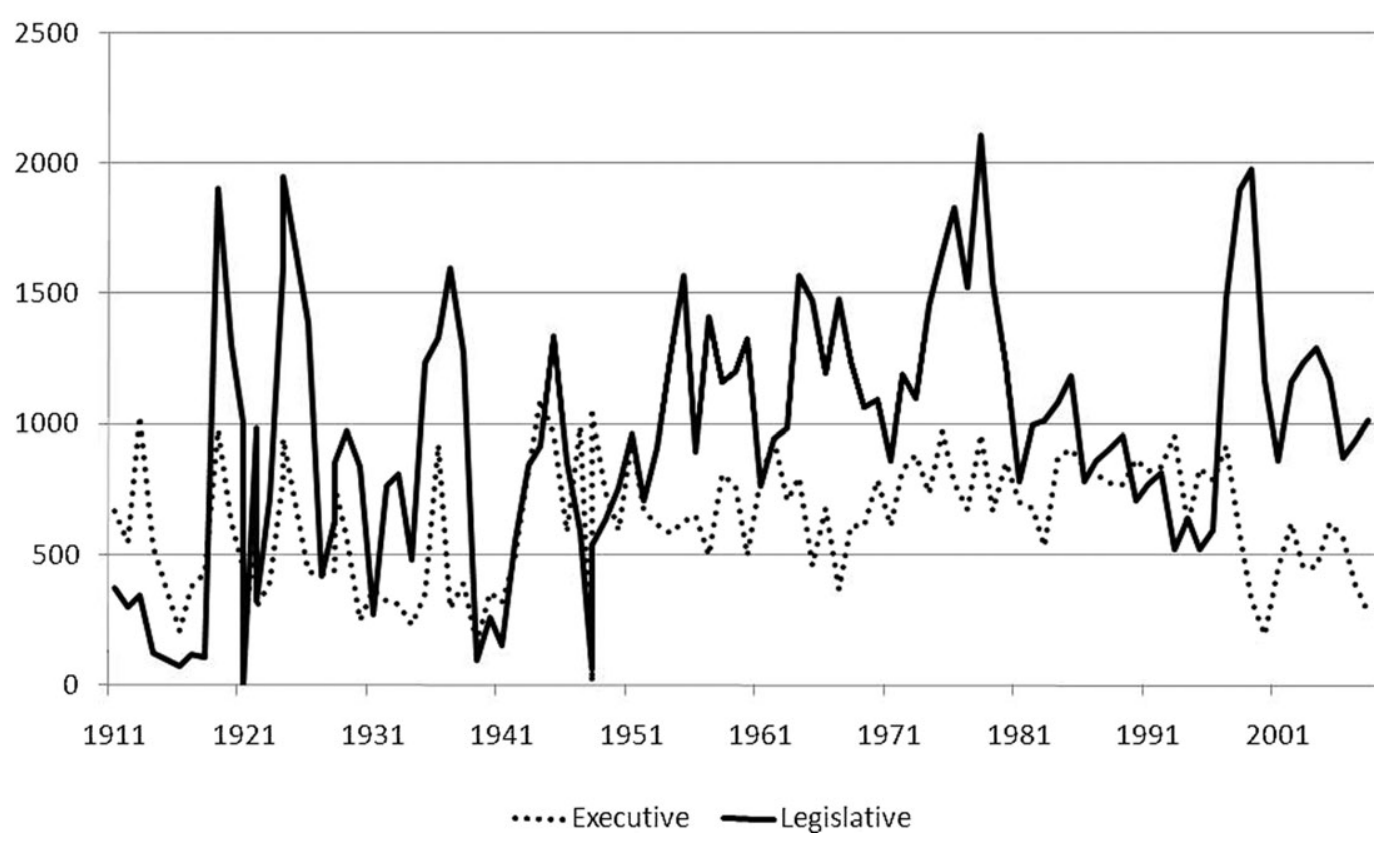

nevertheless represents the most substantial change to the Speech from the Throne in a century of British politics.

\section{Institutional Persistence, Wartime Agenda Setting and Effects of Political Parties}

In order to further assess persistence of the speech as a measure of executive and legislative priorities over time, it is possible to test evolution of the length of the speech in the form of an autoregressive distributed lag (ADL) model. Such a model specification captures the overall degree of persistence of length of the speech over time controlling for the effect of discrete events, where the number of words in the speech in a given speech $\left(\right.$ WORDS $\left._{t}\right)$ is estimated as a function of the total number of words in the previous speech $\left(\right.$ WORDS $\left._{t-1}\right)$, the date of the speech $\left(\mathrm{TIME}_{\mathrm{t}}\right),{ }^{5}$ whether the speech was drafted during war or peacetime $\left(\mathrm{WAR}_{\mathrm{t}}\right)$, whether the Conservative or another party was in control of government (PARTY $_{\mathrm{t}}$ ) and whether the speech opened a special short session $\left(\mathrm{SHORT}_{\mathrm{t}}\right)$. The model therefore accounts for year-on-year continuity of the speech length, any trend over time, the system-level effect of wartime, and differences in the length of the speech and its two sections due to party. This model can be represented in the form:

$$
\begin{aligned}
\text { WORDS }_{\mathrm{t}}= & \alpha 0+\alpha 1 \mathrm{WORDS}_{\mathrm{t}-1}+\alpha 2 \mathrm{TIME}_{\mathrm{t}}+\alpha 3 \mathrm{WAR}_{\mathrm{t}}+ \\
& \alpha 4 \mathrm{PARTY}_{\mathrm{t}}+\alpha 5 \mathrm{SHORT}_{\mathrm{t}}+\varepsilon_{\mathrm{t}}
\end{aligned}
$$


The estimated model (see Table 2) indicates that there is some continuity between speeches, with the autoregressive parameter $(\alpha 1)$ significant at the 99 per cent confidence level and equal to 0.38 . This autoregressive component is more persistent for the legislative section $\left(0.45^{* * *}\right)$ than the executive section $\left(0.25^{* * *}\right)$, indicating that the length of attention dedicated to legislation in the speech is more stable than its expression of executive priorities. The overall length of the speech does not significantly grow over time, with the coefficient for time $(\alpha 2)$ insignificant at the 95 per cent confidence level. This is consistent with the evidence noted from Figure 1 where the speech has not lengthened much in the post-war era. The estimated model confirms, however, that there was a significant reduction $(-496.04 *)$ in the average length of the speech during the wartime periods between 1914 and 1918 and between 1939 and 1945. This is a result of contraction of the legislative section, which is 417.94 words shorter on average during wartime with the executive section unchanged in length. The reduction in length of speech represents a concentration of its attention on the war effort and displacement of legislative issues from this agenda-setting venue, since there is no equivalent downturn in lawmaking production in terms of the number of Acts of Parliament passed during the same periods. Special short sessions of parliament also decrease the length of the speech, with a significant reduction in both the executive and legislative sections, as well as overall.

With respect to party control of government, there are differences in the size of agenda associated with particular political parties. The length of the Speech from the Throne is

\begin{tabular}{|c|c|c|c|}
\hline \multicolumn{4}{|c|}{$\begin{array}{l}\text { Table 2: Words ADL, Controlling for Time, Wars, the } \\
\text { Conservative Party and Special Short Sessions }\end{array}$} \\
\hline & Total & Exec & Leg \\
\hline Words $_{\mathrm{t}-1}$ & $\begin{array}{l}0.38^{* * *} \\
(099)\end{array}$ & $0.25^{* *}$ & $0.45^{* * *}$ \\
\hline Time $_{t}$ & $\begin{array}{c}1.13 \\
(1.79)\end{array}$ & $\begin{array}{c}0.33 \\
(0.81)\end{array}$ & $\begin{array}{c}0.73 \\
(1.35)\end{array}$ \\
\hline War $r_{t}$ & $\begin{array}{l}-496.04^{* *} \\
(166.35)\end{array}$ & $\begin{array}{c}-38.22 \\
(74.56)\end{array}$ & $\begin{array}{l}-417.94^{* *} \\
(129.81)\end{array}$ \\
\hline Party ${ }_{t}$ & $\begin{array}{c}-32.68 \\
(96.65)\end{array}$ & $\begin{array}{l}110.77^{*} \\
(46.26)\end{array}$ & $\begin{array}{r}-124.59 \dagger \\
(74.01)\end{array}$ \\
\hline Short $t_{t}$ & $\begin{array}{l}-1363.18^{* * *} \\
(272.57)\end{array}$ & $\begin{array}{l}-485.79 * * * \\
(126.97)\end{array}$ & $\begin{array}{l}-856.47^{* * *} \\
(208.50)\end{array}$ \\
\hline Constant & $\begin{array}{l}1047.98^{* * *} \\
(160.65)\end{array}$ & $\begin{array}{l}424.16^{* * *} \\
(69.63)\end{array}$ & $\begin{array}{l}620.63^{* * *} \\
(111.48)\end{array}$ \\
\hline Adj. $R^{2}$ & 0.43 & 0.25 & 0.47 \\
\hline $\begin{array}{l}s: N=100, S \\
0.05, * * p \leq C\end{array}$ & $\begin{array}{l}1912, \text { End }=2008 \\
* * 0 \leq 0.001, t p\end{array}$ & & \\
\hline
\end{tabular}


32.68 words shorter for Conservative governments than for their Liberal and Labour opponents although this difference is insignificant. The legislative agenda in Conservative speeches is, on average, 124.59 words shorter, while the executive agenda is in fact 110.77 words longer. Conservative governments therefore tend to focus upon executive priorities in the speech, while Labour and Liberal governments tend to focus upon programmes of legislation. This is consistent with the idea of selective emphasis $\left(\mathrm{Q}_{3}\right)$, as well as with reforming legislative programmes of these parties, such as the governments of Lloyd George and Attlee, compared with Conservative styles of governing (Beer, 1965) even during their most radical period under Thatcher (Bulpitt, 1985). ${ }^{6}$

\section{Policy Agendas and the Speech from the Throne}

To investigate further the executive and legislative agendas communicated in the Speech from the Throne, the UK Policy Agendas Project (www.policyagendas.org.uk) analysed the full text of the speech at the quasi-sentence level, coded according to a UK-adapted version of the policy content coding framework developed by Baumgartner and Jones (www.policyagendas.org) for analysis of agenda setting in the US. The coding system consists of categories for major topics of public policy, such as macroeconomic issues, defence and health and distinct sub-topics within each of these categories, which now number more than 225 (see Table 3 for details of the major topic codes). The project generated a national version of the codebook, retaining the original US categories but providing a more general topic description in addition to UK-specific examples to aid the user (for technical details about origins of the US categories and their coding procedures see Baumgartner et al., 1998). Some topic names are modified, while the policy content remains the same. So, for example, the US 'Public Lands and Water Management' major topic (21) is renamed as 'Public Lands, Water Management, Colonial and Territorial Issues' to reflect the frequency of territorial issues (sub-topic 2105) in the UK - largely attributable to the policy inheritance of the British Empire (and its subsequent break-up and reconstitution as the Commonwealth) along with policy related to home rule of Ireland, Northern Ireland, Scotland and Wales (and later to devolution).

A quasi-sentence (or policy statement) constitutes an expression of a single policy idea or issue while not necessarily a complete sentence (see Volkens, 2002). Generally this unit of analysis is identifiable from the use of punctuation and conjunctions. The transcripts of the Speech from the Throne were blind coded by two researchers first to ascertain whether each quasi-sentence contained any policy content and then to assign a major topic code and sub-topic code to the quasi-sentence. This procedure led to 90 per cent inter-coder agreement for most years. The coders resolved remaining differences through discussion and the project leaders made the final decision in the few cases where coders could not agree. This coding procedure generates the longest known data series of executive and legislative attention in the UK: 101 speeches from the date of the first Parliament Act in 1911 right up to 2008. These data consist of 6,402 quasi-sentences, spanning 4 monarchs, 18 prime ministers and 29 ministries over this 98 -year period. The 


\title{
Table 3: UK Policy Agendas Project Major Topic Codes
}

\author{
0 . Non-policy content \\ 1. Macroeconomics \\ 2. Civil Rights, Minority Issues, Immigration and Civil \\ Liberties \\ 3. Health \\ 4. Agriculture \\ 5. Labour and Employment \\ 6. Education and Culture \\ 7. Environment \\ 8. Energy \\ 10. Transportation \\ 12. Law, Crime and Family Issues \\ 13. Social Welfare \\ 14. Community Development, Planning and Housing Issues \\ 15. Banking, Finance and Domestic Commerce \\ 16. Defence \\ 17. Space, Science, Technology and Communications \\ 18. Foreign Trade \\ 19. International Affairs and Foreign Aid \\ 20. Government Operations \\ 21. Public Lands, Water Management, Colonial and \\ Territorial Issues
}

Note: See http://www.policyagendas.org.uk for the full codebook with sub-topic categories and topic descriptions.

annual number of quasi-sentences (plotted in Figure 3) is strongly correlated with the number of sentences. This provides verification that the coders' classification of quasisentences is consistent over time.

\section{Government Attention to Major Policy Topics in the Speech from the Throne}

Summary statistics for the frequency of major topic mentions are reported in Table A1 in the Appendix. Even excluding speeches opening special short sessions of parliament (in 1921, 1922 and 1948), the minimum values of mentions reveal that each major topic is absent from at least one speech (i.e. the minimum value is zero for all topics with the exception of the non-policy content code). This confirms that it is possible for even the most prominent issues such as social welfare (13) and macroeconomic issues (1) to be left off the agenda at some point. The mean values of major topic mentions confirm that there are, on average, more legislative mentions of all topics, with the exception of defence (16), international affairs (19) and public lands and territorial issues (21). This finding is consistent with the specific executive character of each of those topics, providing support for the theoretical expectation of differences between legislative and executive priorities $\left(\mathrm{Q}_{2}\right)$. 
Figure 3: Number of Sentences and Quasi-sentences (Policy Statements)

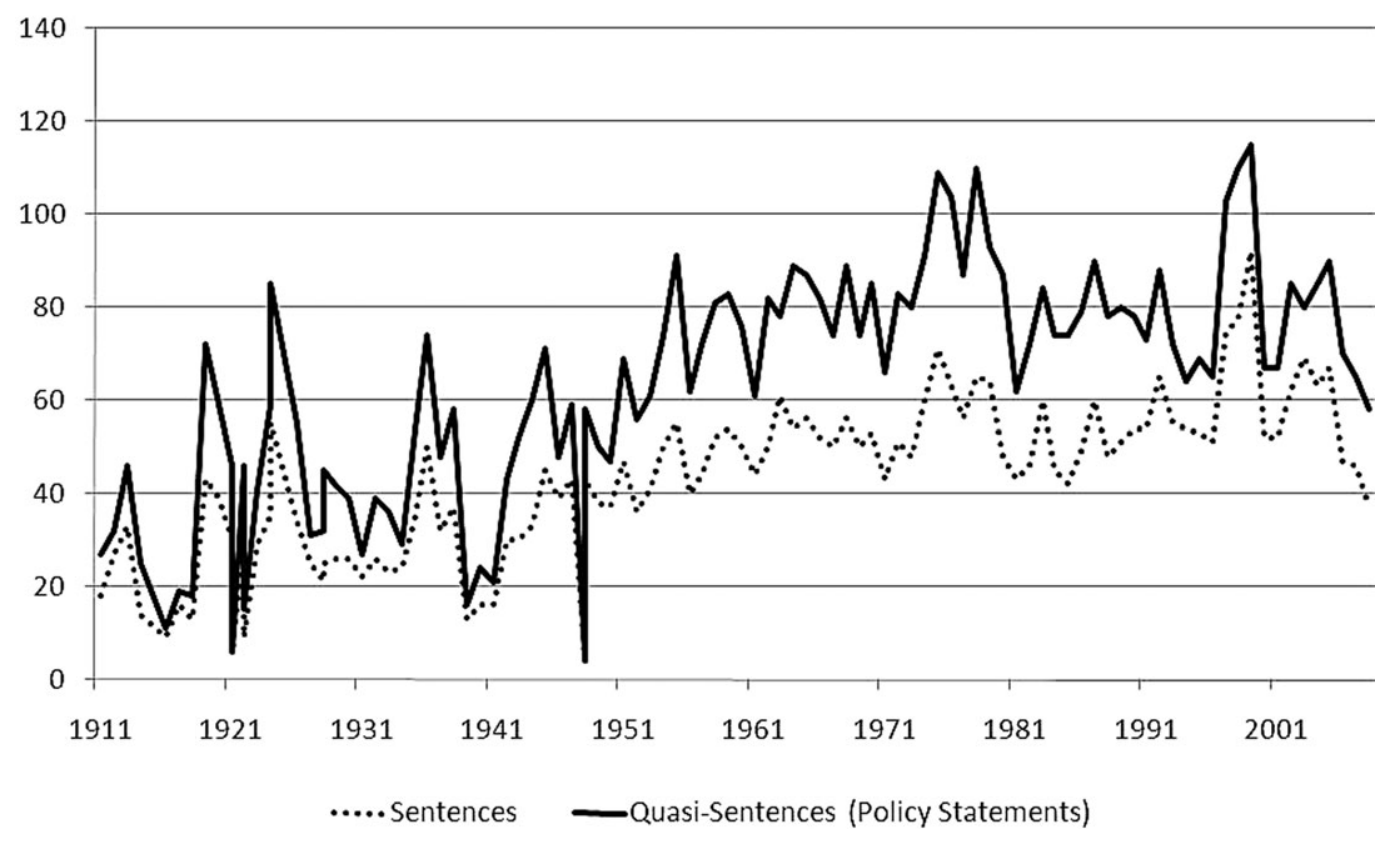

The coded data on the topic attention of the Speech from the Throne also enable analysis of the evolving policy priorities of UK governments over time. The frequencies of topic mentions in each speech allocated to each major topic are illustrated in the graphs in Figure 4. Each of the topics is illustrated against the same scale of $y$-axis to provide an indication of relative differences in attention to different issues, as well as variation in the level of attention to particular topics. The mean levels of these series confirm the relative domination of the agenda by macroeconomics (1), defence (16), international affairs and foreign aid (19) and public lands, water management, colonial and territorial issues (21). Furthermore, trends in frequencies of topic mentions reveal the rise and fall of particular issues during 100 years of British government. The topic of defence was high on the agenda during the First and Second World Wars, with increasing attention to the economy in the 1930s and also between the 1960s and 2000s, and a gradual decline in attention to territorial and commonwealth issues over the post-war period. Each of these trends reflects substantive changes in policy content of the speech. For example, defence dominated the November 1939 speech, with statements such as 'The prosecution of the war commands the energies of all My subjects' and 'Throughout the world My Navies, together with the Merchant Navy and Fishing Fleets, are keeping free and open the highways of the sea'. Likewise, the break-up of the Empire during the post-war period prompted specific discussion of decolonisation, noting in the November 1956 speech: 'My Ministers will be concerned to further the progress and constitutional development of the territories for whose well-being 


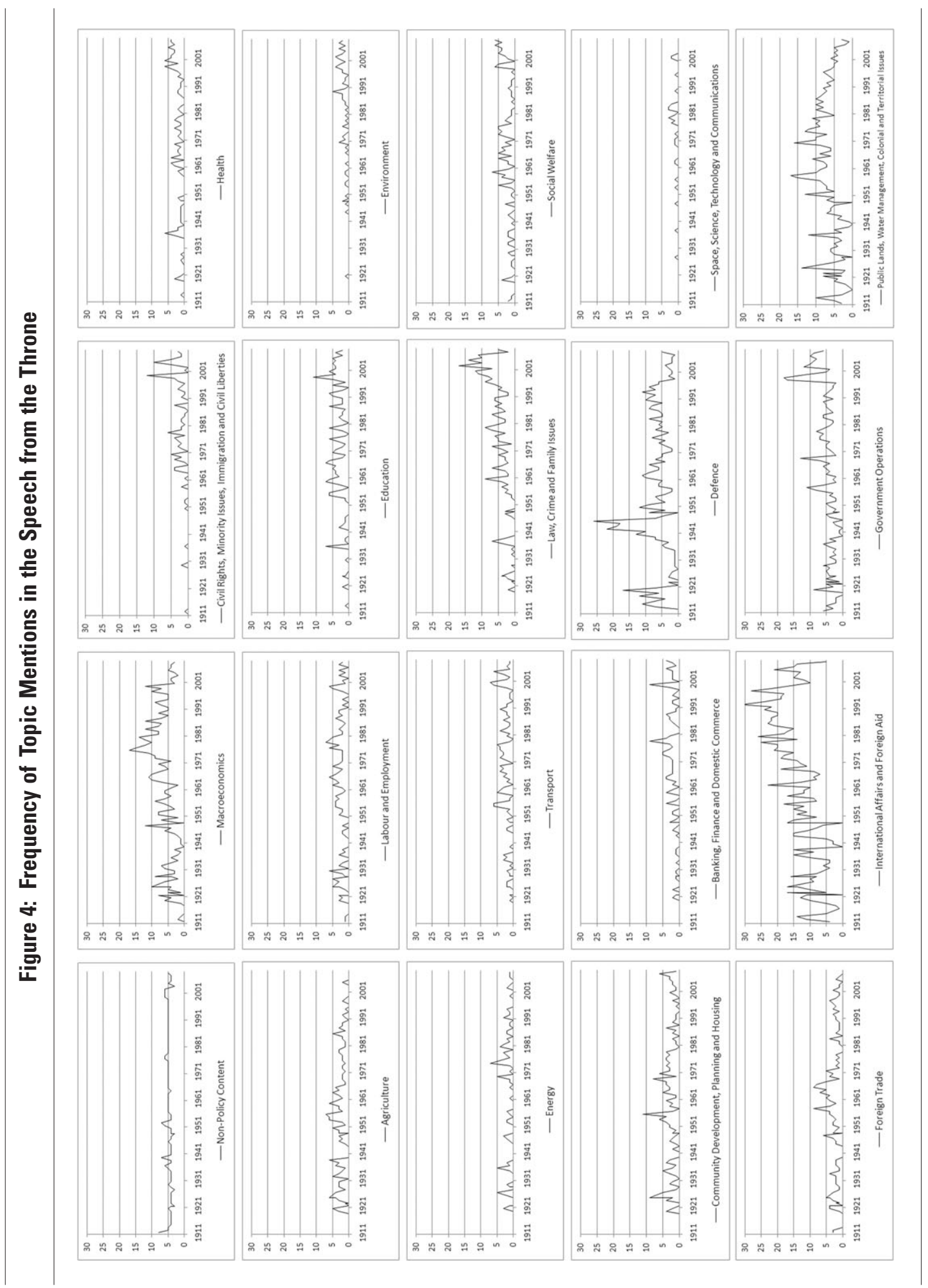


they are responsible'. The British government has also used the speech to highlight economic concerns and policies, such as the November 1984 speech stating: 'my Government remains deeply concerned about unemployment and will continue policies designed to achieve better opportunities for employment and to help the unemployed obtain the training or work experience needed to fill them'. The style and format of the text has remained quite stable over such a long period while the policy content of the speech changes over time.

Also notable is the relative absence of attention prior to the Second World War to topics such as civil rights, minority issues, immigration and civil liberties (2), education (3) to some degree, environment (7) and space, science, technology and communications (17). It is evident, moreover, that the attention of British government to health (3), education (6), transport (10) and law, crime and family issues (12) has increased in the post-war period. These trajectories of attention reflect, respectively, the decline in Britain's status as a world power, its loss of empire and the rise of domestic issues as topics of public concern. The graphs also illustrate that topic attention of the Speech from the Throne appears to be both cyclical and punctuated - consistent with previous studies (Jennings and John, 2009; John and Jennings, 2010).

\section{Persistence of Topic Attention in the Speech from the Throne and Partisan Effects}

The persistent (autoregressive) character of attention of the Speech from the Throne to major policy topics can be further assessed through estimation of an ADL model of the frequency of topic mentions.

$$
\begin{aligned}
\text { TOPIC }_{\mathrm{t}}= & \alpha 0+\alpha 1 \mathrm{TOPIC}_{\mathrm{t}-1}+\alpha 2 \mathrm{TIME}_{\mathrm{t}}+\alpha 3 \mathrm{WAR}_{\mathrm{t}}+ \\
& \alpha 4 \text { PARTY }_{\mathrm{t}}+\alpha 5 \mathrm{SHORT}_{\mathrm{t}}+\varepsilon_{\mathrm{t}}
\end{aligned}
$$

where the number of topic mentions $\left(\right.$ TOPIC $_{t}$ ) is a function of the number of mentions in the previous speech $\left(\mathrm{TOPIC}_{\mathrm{t}-1}\right)$, historical trend $\left(\mathrm{TIME}_{\mathrm{t}}\right)$, whether the speech was delivered during war or peacetime $\left(\mathrm{WAR}_{\mathrm{t}}\right)$, whether the Conservative or another party was in control of government $\left(\right.$ PARTY $\left._{\mathrm{t}}\right)$ and whether the speech opened a special short session of parliament $\left(\mathrm{SHORT}_{\mathrm{t}}\right)$. The results that are reported in Table 4 for each major topic indicate varying degrees of persistence in topic attention. ${ }^{7}$ The lagged value of topic mentions is significant at the 95 per cent confidence level in fifteen cases and at the 90 per cent level in two others. These range in value from weak persistence $(0.166 \dagger)$ for health (3) and strong persistence $\left(0.491^{* * *}\right)$ for foreign trade (18). These findings are consistent with the idea that the policy content of the Speech from the Throne is quite stable over time $\left(Q_{1}\right)$, despite evidence of punctuations in political attention for a later part of this period between 1940 and 2005 (see John and Jennings, 2010). There is also varied evidence of growth over time, with trend $\left(\mathrm{TIME}_{\mathrm{t}}\right)$ positive and significant at the 95 per cent confidence level for eleven of the nineteen major topics - for civil rights, minority issues and civil liberties (inclusive of immigration) (2), health (3), education (6), environment (7), transport (10), law, crime and family issues (12), welfare (13), domestic commerce (15), international affairs (19) and government operations (20). This growth over time is greatest in magnitude for the law and 


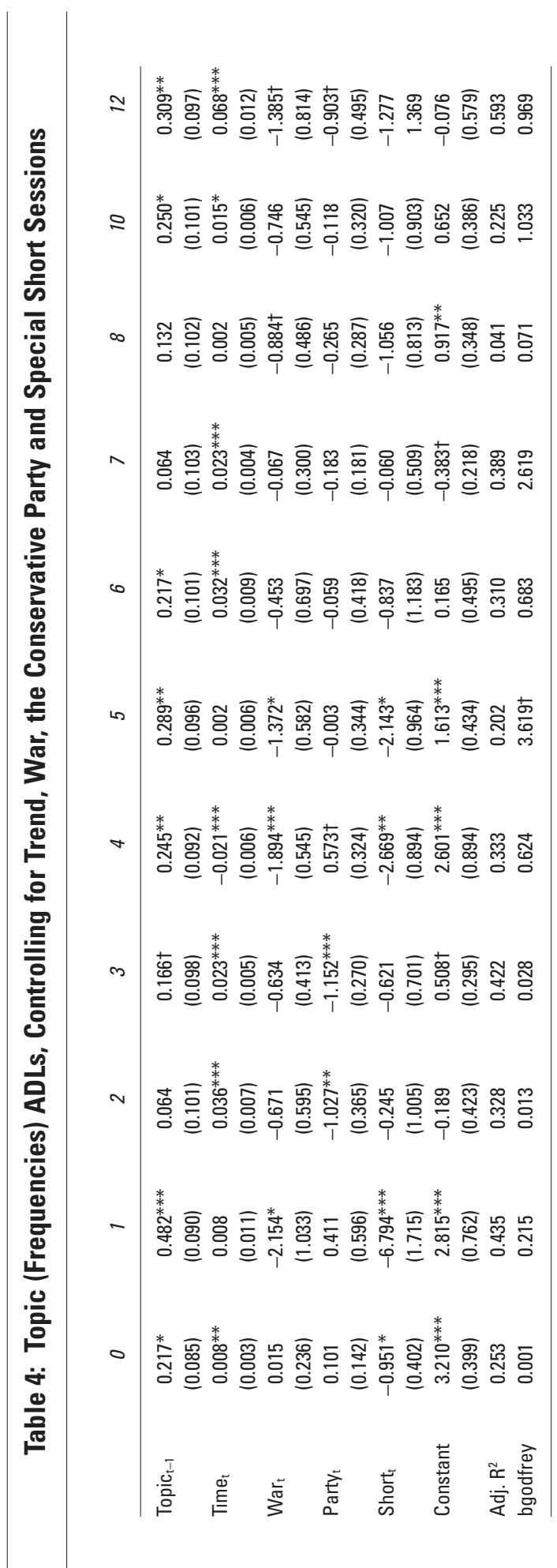

产墨 $\approx z$

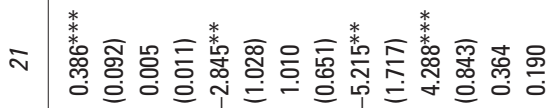

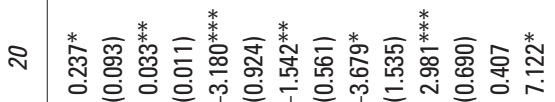

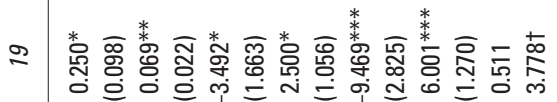

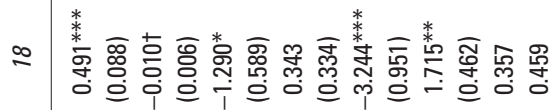

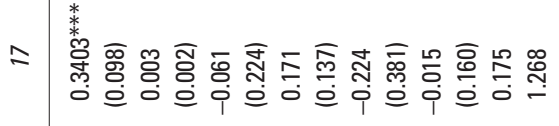

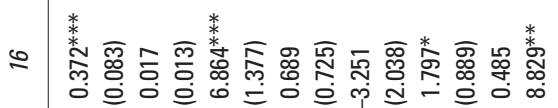

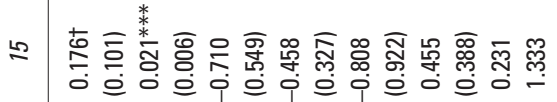

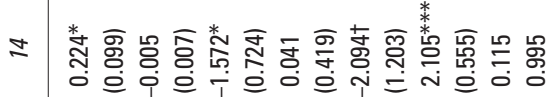

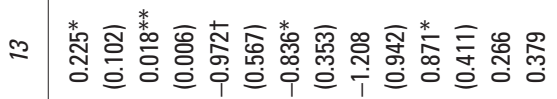
竞䓂 
order and international affairs topics. One noticeable exception, with all the other time parameters insignificant, is the significant decrease in attention to agriculture (4) - reflecting the decline in political attention to agricultural production in the post-war era. There is also a marginal decrease in attention to foreign trade (18), significant at the 90 per cent confidence level.

The impact of war upon mentions also varies across topics, with negative effects for the economy (1), agriculture (4), labour and employment (5), energy (8), law, crime and family issues (12), housing (14), foreign trade (18), government operations (20) and territorial issues (21). Of particular interest, the number of mentions of international affairs (19) also decreases during wartime - as attention is shifted to defence (16), with an increase in mentions of that major topic significant at the 95 per cent confidence level. These results provide some indication of the relative persistence of priorities of British government over time as well as of decreases in attention to a range of topics during wartime, consistent with the idea of issue intrusion and the impact of exogenous shocks $\left(\mathrm{Q}_{4}\right)$. For speeches opening special short sessions of parliament, there is a significant decrease in the average number of topic mentions for the economy (1), agriculture (4), labour and employment (5), housing (14), foreign trade (18), international affairs and foreign aid (19), government operations (20) and territorial issues (21). Again, the results show how these speeches for special short sessions are distinct from general use of the speech by British government.

The ADL models also reveal a few noticeable differences between political parties in their attention to particular issues. On average, Conservative governments assign less attention to civil rights and minority issues (2), health (3), law, crime and family issues (12), welfare (13) and government operations (20), but more attention to international affairs (19). Overall, such results are consistent with characterisations of the selective emphasis of political parties in British politics $\left(\mathrm{Q}_{3}\right)$.

A time series cross-sectional (panel) ADL model is also estimated to capture the general autoregressive character of attention allocation across all topics (estimated using panelcorrected standard errors). The use of a time series cross-sectional model has the advantage of uncovering a general relationship between attention of British government across all topics and the effect of past levels of attention and other explanatory variables, rather than an issue-specific relationship. In this way, we are able to measure persistence of the Speech from the Throne in general with a focus on content similar to our earlier analysis on its length. The data are organised in the form topic $(i) *$ year $(t)$, so that the basic ADL model considered earlier is now represented in the form

$$
\begin{aligned}
\text { TOPIC }_{\mathrm{it}}= & \alpha 0+\alpha_{\mathrm{it}-1} \text { TOPIC }_{\mathrm{it}-1}+\alpha_{\mathrm{it}} \mathrm{TIME}_{\mathrm{it}}+\alpha_{\mathrm{it}} \mathrm{WAR}_{\mathrm{it}}+ \\
& \alpha_{\mathrm{it}} \text { PARTY }_{\mathrm{it}}+\alpha_{\mathrm{it}} \mathrm{SHORT}_{\mathrm{it}}
\end{aligned}
$$

The results presented in the final column of Table 4 confirm that topic attention is autoregressive $\left(0.765^{* * *}\right)$, indicating that past values of topic mentions are strongly predictive of future values with an overall reduction in mentions during wartime and for 
special short sessions of parliament (each significant at the 99 per cent confidence level). These findings offer further confirmation of $Q_{1}$, in incremental evolution of the policy agenda over time, as well as confirmation of $\mathrm{Q}_{4}$, in issue intrusion in response to the exogenous shock of war and to special short sessions. The speech also reverts to its long-run equilibrium (mean) of mentions per topic, 0.823 - significant at the 99 per cent confidence level. There is no significant finding of growth over time for the overall cross-section of topic mentions, suggesting that the growth of specific issues is a product of attention shifting between topics rather than an increase in volume of the policy agenda (consistent with the findings in Jennings et al., 2009). ${ }^{8}$

\section{Agenda Scope and Issue Diversity of the Speech from the Throne}

Finally, the analysis turns to consider the issue diversity of government attention in the Speech from the Throne. The scope of executive attention is equal to the number of major or sub-topic categories that are referred to in each speech. This measure does not have the same potential for growth as the number of policy statements because its value is bounded between zero and nineteen major topics or 225 sub-topics. This is plotted in Figure 5. In terms of sub-topic scope, it does appear that in recent times the government has handled a wider range of issues than in the pre-Second World War era. This is quite plausible in light of expansion of the state during this period and its proliferation of policy-making activities

Figure 5: Major and Sub-topic Scope

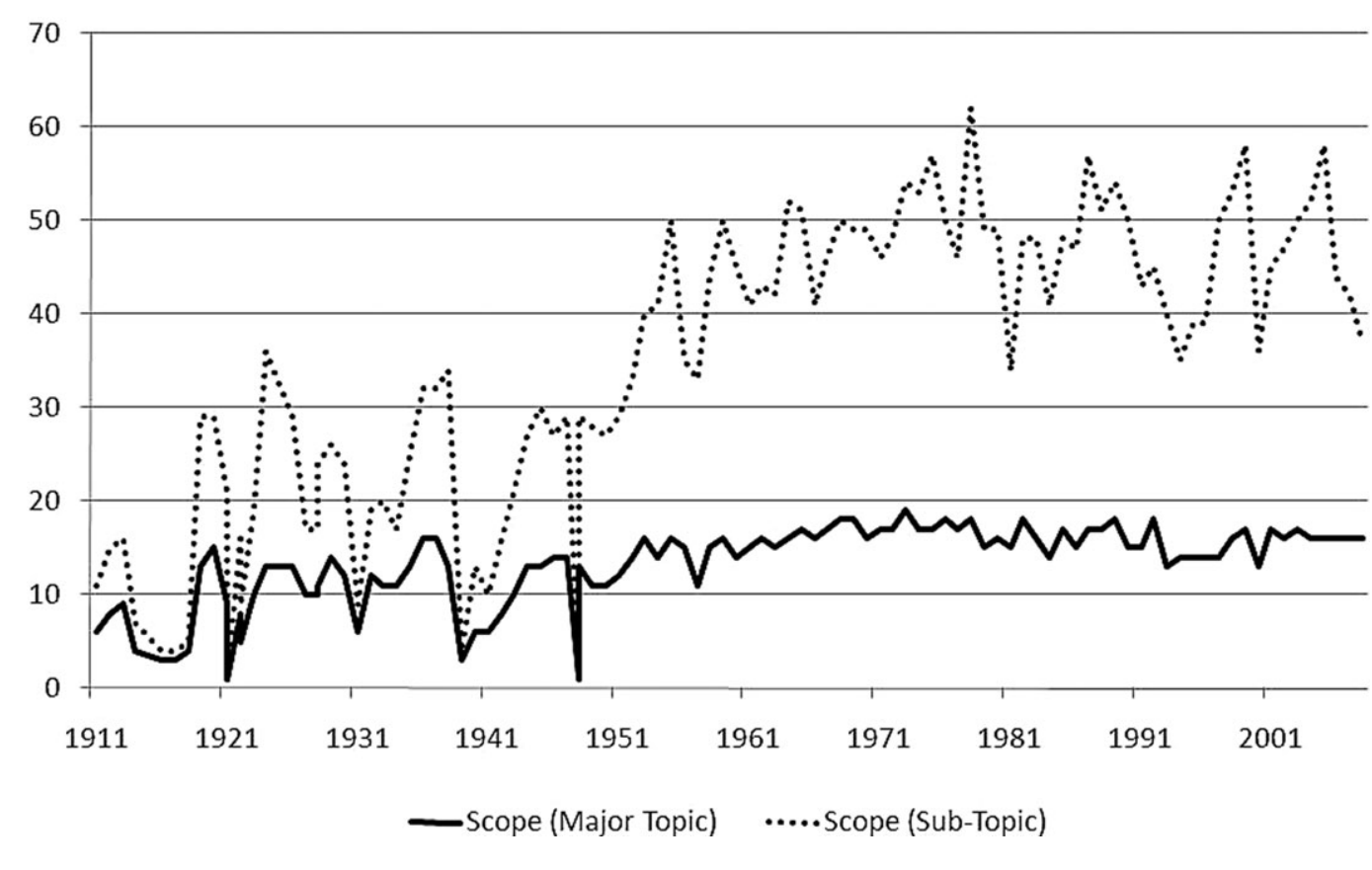


and bureaucratic capacity. For major topics, agenda scope is quite stable, only decreasing noticeably during wartime.

To measure the issue diversity of attention across the entire agenda, entropy scores are calculated for the content of the speech according to the major topic codes. The measure of entropy used here, Shannon's H (1948), is adapted from information theory to estimate the issue diversity of policy-making attention (Jones and Baumgartner, 2005). Shannon's H is a probabilistic measure of the spread of objects or observations across a defined number of (discrete) nominal categories. This is equal to the logarithm of the sum of probabilities of the different possible states in a system. If the agenda has a high degree of entropy, there is greater uncertainty concerning which topics government is attending to. If government concentrates upon a small number of topics, there is a low degree of entropy in the system. This measure of diversity is represented in the form

$$
\mathrm{H}=(-1) \sum_{i=1}^{n} \mathrm{p}\left(\mathrm{x}_{\mathrm{i}}\right) \ln \left(\mathrm{p}\left(\mathrm{x}_{\mathrm{i}}\right)\right)
$$

where entropy scores $(\mathrm{H})$ are estimated as the negative sum for all topics of the likelihood, $\mathrm{p}(\mathrm{x})$, that an object $x$ (in this instance a policy statement in the executive's speech) falls within a particular topic $i$, multiplied by the natural log of that likelihood. Since logs of zero cannot be calculated, it is assumed that $0 * \ln (0)=0$ for topics where there were no policy statements in a given year. The maximum possible entropy score for the nineteen major topic codes is equal to the natural $\log$ of 19 (i.e. 2.944). The maximum possible entropy score for the 225 sub-topic codes is 5.416. An entropy score of 0 indicates that attention is concentrated in a single topic, while a score of 2.944 indicates that attention is equally spread across all nineteen major topics such that each issue receives 5.26 per cent of the attention.

The issue diversity of the Speech from the Throne is plotted for both major topics and sub-topics in Figure 6. This reveals that the dispersion of the agenda drops suddenly during wartime periods (between 1914 and 1918 and between 1939 and 1945) and also during the recall of parliament in December 1921 to approve the Articles of Agreement for creation of the Irish Free State and in 1948 concerning passage of the third Parliament Act. Interestingly in terms of responsiveness of the political agenda, its return to the peacetime level of issue diversity was gradual and started during rather than just after the war years. After the initial response of executive government to conflict - the prioritisation of defence - was complete, the policy agenda became increasingly diverse as the political system became more capable and willing to attend to a wider variety of topics. The level of issue diversity appears to cycle somewhat during other periods, consistent with the fixed bounds of the entropy measure which ensure that it reverts to its long-run equilibrium (mean). In previous studies (John and Jennings, 2010) we identified a gradual post-war expansion of issue diversity of the agenda, with a subsequent contraction in response to economic crises of the 1970s and political concern with international affairs during the height of the cold war era. The pattern is, as might be expected, somewhat more volatile for sub-topics, climbing more steeply in the post-war era as governments addressed a wider range of 
Figure 6: Major and Sub-topic Entropy

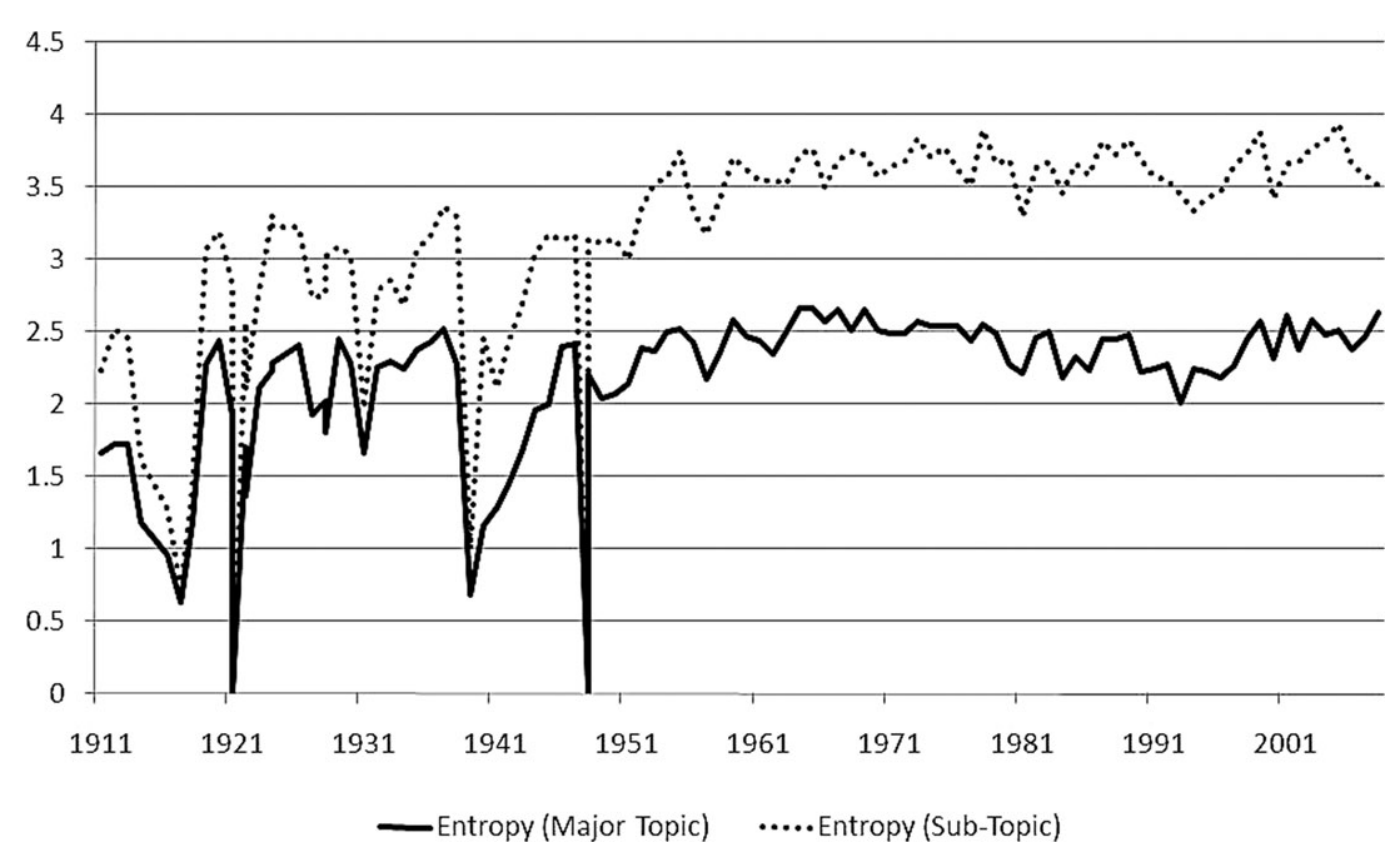

specific issues (though in recent years this has become rather more volatile and has signs of a possible decline). This pattern of agenda diversity is attributable to a process of issue intrusion where certain core issues are associated with a less diverse agenda while other more peripheral or conditional topics are associated with greater agenda diversity (see Jennings et al., 2009).

\section{Conclusion}

Overall, then, what can be concluded about the nature of the political agenda in the Speech from the Throne? The principal and perhaps most surprising finding is the relative institutional and policy stability of the Speech from the Throne over time. Despite two world wars, major changes to the social welfare state, the break-up of the British Empire, economic crises and numerous handovers of power between the major political parties, the size of the executive agenda presented in the speech has tended to remain stable over the last hundred sessions of parliament. In large part, the attention of government to specific issues has also been persistent, with strong relationships between the size of the agenda at time $t$ and its past value at time $t-1$. This long-standing institution has remained a forum for agenda setting, with variations in issue priorities reflecting the wider process of adaptation and evolution of modern British government in response to social, economic and political change throughout the twentieth century. 
Despite the reduction of capacity of the core executive in modern British government/ governance (e.g. Rhodes, 1994; 1997), the centre continues to use this annual institution as a direct means to signal its executive and legislative priorities and set the national agenda.

There are differences and changes in the content of the Speech from the Throne over time, however. For one, there is evidence of growth in attention to several issues (e.g. health, education, environment, welfare, international affairs, government operations and law, crime and family issues), much of which reflects growth in both the function and capabilities of the modern British state. There is also a marked decline in the amount of attention government assigns to agriculture, again reflecting the decreased concern of the state with food production. Overall, there has been no statistically significant increase in the total number of policies mentioned in the speech, indicating a trading of priorities within a fairly consistently sized agenda space. Furthermore, parties exhibit a selective emphasis in their use of the speech, with Conservatives delivering speeches with a significantly greater emphasis on executive priorities compared to Labour and Liberal governments. In terms of attention to specific topics, Conservative governments also tend to pay less attention to civil rights and minority issues, health, law, crime and family issues, social welfare and government operations, but historically assign more attention to international affairs than other governments. The agenda-setting function of the speech therefore reflects the issue strengths of the major political parties in Britain.

Other changes also affect the Speech from the Throne. The external shock of the two world wars led to an overall decrease in the length of the speech, in particular in its legislative priorities. These shocks and special parliamentary sessions further led to a decrease in the scope and diversity of the overall agenda. These are effects that one would expect, but also confirm that the content coding system used by the UK Policy Agendas Project is a robust measure of variations in the attention of British government. Issue diversity and issue attention further show a cyclical and punctuated pattern, along with a drift upwards in diversity of the agenda after 1992 (see also John and Jennings, 2010).

Through analysis of the content of the Speech from the Throne, this article has demonstrated the stability and the dynamics of the agenda of British government in both its executive and legislative priorities - with persistence and variations across topics and over time. While the analyses presented in this article are important and interesting in their own right, it is our hope that these data will stimulate further discussion of, and research into, agenda setting in British politics. These data show that the content of the Speech from the Throne provides a window on executive and legislative priorities that is stable over 100 sessions of parliament - demonstrating persistence of this agenda-setting institution and revealing real shifts in political attention over time. Some of the findings are consistent with prevailing wisdom about the British political system, while some are not (or at least require further investigation). Our hope is that through future use of this and other similarly constructed data sets, existing theories of British politics will be tested through robust empirical analyses and that new theories will be developed on the basis of those findings. 
Appendix

Table A1: Topic Mentions Summary Statistics (Excluding Special Short Sessions)

\begin{tabular}{|c|c|c|c|c|c|c|c|c|c|}
\hline Topic & & Total & Exec & Leg & Topic & & Total & Exec & Leg \\
\hline \multirow[t]{4}{*}{0} & Mean & 4.73 & 1.33 & 3.41 & 12 & Mean & 3.44 & 0.26 & 3.18 \\
\hline & SD & 0.81 & 0.74 & 0.62 & & SD & 3.56 & 0.63 & 3.40 \\
\hline & Min & 3 & 0 & 2 & & Min & 0 & 0 & 0 \\
\hline & Max & 8 & 5 & 6 & & Max & 17 & 3 & 17 \\
\hline \multirow[t]{4}{*}{1} & Mean & 5.74 & 0.51 & 5.23 & 13 & Mean & 1.73 & 0.02 & 1.71 \\
\hline & SD & 3.67 & 1.29 & 3.36 & & SD & 1.82 & 0.14 & 1.80 \\
\hline & Min & 0 & 0 & 0 & & Min & 0 & 0 & 0 \\
\hline & Max & 17 & 11 & 15 & & Max & 7 & 1 & 7 \\
\hline \multirow[t]{4}{*}{2} & Mean & 1.27 & 0.13 & 1.13 & 14 & Mean & 2.16 & 0 & 2.16 \\
\hline & SD & 2.05 & 0.40 & 2 & & SD & 2.09 & 0 & 2.09 \\
\hline & Min & 0 & 0 & 0 & & Min & 0 & 0 & 0 \\
\hline & Max & 12 & 2 & 12 & & Max & 11 & 0 & 11 \\
\hline \multirow[t]{4}{*}{3} & Mean & 1.37 & 0.01 & 1.36 & 15 & Mean & 1.52 & 0.04 & 1.48 \\
\hline & SD & 1.53 & 0.10 & 1.52 & & SD & 1.75 & 0.20 & 1.71 \\
\hline & Min & 0 & 0 & 0 & & Min & 0 & 0 & 0 \\
\hline & Max & 6 & 1 & 6 & & Max & 9 & 1 & 9 \\
\hline \multirow[t]{4}{*}{4} & Mean & 1.99 & 0.17 & 1.82 & 16 & Mean & 5.84 & 4.67 & 1.16 \\
\hline & SD & 1.80 & 0.48 & 1.83 & & SD & 4.68 & 3.44 & 2.13 \\
\hline & Min & 0 & 0 & 0 & & Min & 0 & 0 & 0 \\
\hline & Max & 7 & 3 & 7 & & Max & 26 & 15 & 11 \\
\hline \multirow[t]{4}{*}{5} & Mean & 2.18 & 0.01 & 2.17 & 17 & Mean & 0.33 & 0 & 0.33 \\
\hline & SD & 1.77 & 0.10 & 1.77 & & SD & 0.70 & 0 & 0.70 \\
\hline & Min & 0 & 0 & 0 & & Min & 0 & 0 & 0 \\
\hline & Max & 7 & 1 & 7 & & Max & 3 & 0 & 3 \\
\hline \multirow[t]{4}{*}{6} & Mean & 2.26 & 0.04 & 2.21 & 18 & Mean & 2.26 & 0.81 & 1.45 \\
\hline & SD & 2.36 & 0.25 & 2.32 & & SD & 1.94 & 1.18 & 1.55 \\
\hline & Min & 0 & 0 & 0 & & Min & 0 & 0 & 0 \\
\hline & Max & 11 & 2 & 11 & & Max & 9 & 6 & 9 \\
\hline \multirow[t]{4}{*}{7} & Mean & 0.76 & 0.15 & 0.60 & 19 & Mean & 13.53 & 12.10 & 1.43 \\
\hline & SD & 1.08 & 0.48 & 0.92 & & SD & 6.49 & 5.66 & 1.91 \\
\hline & Min & 0 & 0 & 0 & & Min & 0 & 0 & 0 \\
\hline & Max & 5 & 3 & 5 & & Max & 31 & 28 & 9 \\
\hline \multirow[t]{4}{*}{8} & Mean & 0.94 & 0.04 & 0.90 & 20 & Mean & 4.77 & 0.33 & 4.44 \\
\hline & SD & 1.38 & 0.20 & 1.33 & & SD & 3.25 & 0.97 & 2.81 \\
\hline & Min & 0 & 0 & 0 & & Min & 0 & 0 & 0 \\
\hline & Max & 7 & 1 & 6 & & Max & 18 & 8 & 17 \\
\hline \multirow[t]{4}{*}{10} & Mean & 1.68 & 0.06 & 1.62 & 21 & Mean & 6.58 & 3.72 & 2.86 \\
\hline & SD & 1.70 & 0.32 & 1.65 & & SD & 3.53 & 2.62 & 1.88 \\
\hline & Min & 0 & 0 & 0 & & Min & 0 & 0 & 0 \\
\hline & Max & 7 & 2 & 7 & & Max & 17 & 13 & 8 \\
\hline
\end{tabular}

(Accepted: 5 January 2010) 


\section{About the Authors}

Will Jennings is ESRC Research Fellow in the School of Social Sciences, University of Manchester, where he holds an ESRC Research Fellowship 'Going for Gold: The Olympics, Risk and Risk Management' that explores the nature of both governmental and organisational responses to risk in bidding for, planning and staging of the Olympic Games. He is also co-investigator on the UK Policy Agendas Project and his research interests include executive government, public opinion and public policy and the management of risk in mega-projects and mega-events.

Will Jennings, School of Social Sciences, The University of Manchester, Oxford Road, Manchester M13 9PL; email: will.jennings@manchester.ac.uk

Shaun Bevan is Research Associate in the Institute for Political and Economic Governance, University of Manchester, and a doctoral student in political science at The Pennsylvania State University. He is the project coordinator for the UK Policy Agendas Project. In addition to the comparative analysis of policy agendas, his research focuses on the life cycle of voluntary associations in the US, in particular their formation, density and survival.

Shaun Bevan, School of Social Sciences, The University of Manchester, Oxford Road, Manchester M13 9PL; email: shaun.bevan@manchester.ac.uk

Peter John is the Hallsworth Chair of Governance in the School of Social Sciences, University of Manchester, where he is co-director of the Institute for Political and Economic Governance. He is author of Analysing Public Policy (Continuum, 1998; new edition forthcoming in 2011) and Local Governance in Western Europe (Sage, 2001). He leads the UK Policy Agendas Project and heads a programme of research on experiments in civic participation (www.civicbehaviour.org).

Peter John, School of Social Sciences, The University of Manchester, Oxford Road, Manchester M13 9PL; email: peter.john@manchester.ac.uk

\section{Notes}

This research is an output of the project, Legislative Policy Agendas in the UK, funded by the UK Economic and Social Research Council (Reference R105938), part of a European collaboration funded by the European Science Foundation (ESF): a EUROCORES ECRP 2007 project called The Politics of Attention: West European Politics in Times of Change, led by Stefaan Walgrave, Department of Political Science, University of Antwerp. An earlier version of the article was presented at the Political Studies Association Parliaments and Legislatures Specialist Group Annual Conference, London, 24 June 2009. Thanks to participants at that event for their comments. Thanks also to the journal editor and three anonymous referees for their comments. Further details of the UK Policy Agendas Project are available on the project website, http://www.policyagendas.org.uk.

1 These speeches sometimes contain ceremonial and symbolic statements about the government's achievements and major domestic or international events, but these represent a small part of the content.

2 Until 1928, the start of a new parliamentary session generally occurred early in the year, in either January or February. Since then, the parliamentary year has begun in October or November except after an election, where the first act of business for an incoming government is the opening of parliament with a Speech from the Throne.

3 Official state visits of the monarch are reported in the Speech from the Throne. On average, one or two visits are mentioned in the executive section per speech. This consistent number of mentions means that state visits do not affect the variance of attention to international affairs.

4 This excludes speeches opening special short sessions of parliament, which are not representative of general use of the speech by British government. Including these speeches does not alter any general inferences from analysis of the results in Table 1, but reduces the mean and increases the standard deviation of the word count of both the legislative and executive sections.

5 This does not quite correspond to the calendar year because there are a number of years in which there was more than one Speech from the Throne $(1921,1922,1928,1948)$ and a few others where there was no speech at all $(1915,1925,1949)$ due to differences between the parliamentary cycle and calendar year (which can create a gap of more than twelve months between speeches).

6 A version of the model which only considers the post-war period (1946-2008), not presented here, produces the same general inferences. However, the effect for the lagged word count is no longer significant for the executive section of the speech and the effect of the party variable is larger and more significant in both the executive and legislative analyses, retaining the same sign.

7 These results are consistent whether comparing Conservative to non-Conservative for the full period or Conservative to Labour for the post-war period, or whether using a difference in means test or a party variable within the ADL framework.

8 The same general inferences are drawn if this model is estimated for the post-war period only (1946-2008). The only notable exception is that lagged mentions of agriculture are now negative and insignificant. This is likely due to a decrease in government's attention to agriculture over the post-war period. 


\section{References}

Bagehot, W. (1872) The English Constitution, second edition. London: Henry S. King and Company.

Bara, J. (2005) 'A Question of Trust: Implementing Party Manifestos', Parliamentary Affairs, 58 (3), 585-99.

Baumgartner, F. R. and Jones, B. D. (1993) Agendas and Instability in American Politics. Chicago IL: University of Chicago Press.

Baumgartner, F. R., Jones, B. and MacLeod, M. C. (1998) 'Lessons from the Trenches: Quality, Reliability, and Usability in a New Data Source', The Political Methodologist, 8 (2), 1-11.

Beer, S. H. (1965) Modern British Politics: A Study of Parties and Pressure Groups. London: Faber.

Bevir, M. and Rhodes, R. A. W. (2003) Interpreting British Governance. London: Routledge.

Breeman, G., Lowery, D., Poppelaars, C., Resodihardjo, S. L., Timmermans, A. and de Vries, J. (2009a) 'Political Attention in a Coalition System: Analyzing Queen's Speeches in the Netherlands 1945-2007', Acta Politica, 44 (1), 1-27.

Breeman, G., Chaqués, L., Green-Pedersen, C., Jennings, W., John, P., Mortensen, P. B., Palau, A. and Timmermans, A. (2009b) "Comparer les agendas gouvernementaux: les "discourse du trône" aux Pays-Bas, au Royaume-Uni, au Danemark et en Espagne', Revue International de Politique Comparée, 16 (3),special issue 'Les Agendas Politiques', 405-21.

Budge, I. and Farlie, D. (1983) 'Party Competition - Selective Emphasis or Direct Confrontation? An Alternative View with Data', in H. Daalder and P. Mair (eds), West European Party Systems: Continuity and Change. London: Sage, pp. 267-305.

Budge, I. and Hofferbert, R. I. (1992) 'The Party Mandate and the Westminster Model: Party Programmes and Government Spending in Britain, 1948-1985', British Journal of Political Science, 22 (2), 151-82.

Budge, I., Klingeman, H.-D., Volkens, A., Bara, J. and Tanenbaum, E. (2001) Mapping Policy Preferences: Estimates for Parties, Electors, and Governments 1945-1998.Oxford: Oxford University Press.

Bulpitt, J. (1985) 'The Discipline of the New Democracy: Mrs Thatcher's Domestic Statecraft', Political Studies, 34 (1), 19-39.

Canes-Wrone, B. (2001) ‘A Theory of Presidents' Public Agenda Setting', Journal of Theoretical Politics, 13 (2), 183-208.

Canes-Wrone, B. (2005) Who Leads Whom? The Policy Effects of Presidents' Relationship with the Masses. Chicago IL: University of Chicago Press.

Carmines, E. G. and Stimson, J. A. (1989) Issue Evolution: Race and the Transformation of American Politics. Princeton NJ: Princeton University Press.

Cobb, R. W. and Elder, C. D. (1983) Participation in American Politics: The Dynamics of Agenda-Building. Baltimore MD: Johns Hopkins University Press.

Cohen, J. E. (1995) 'Presidential Rhetoric and the Public Agenda', American Journal of Political Science, 39 (1), 87-107.

Cohen, J. E. (1997) Presidential Responsiveness and Public Policy-Making: The Publics and the Policies that Presidents Choose. Ann Arbor MI: University of Michigan Press.

Foley, M. (1993) The Rise of the British Presidency. Manchester: Manchester University Press.

Franklin, M., Mackie, T. and Valen, H. (eds) (1992) Electoral Change: Responses to Evolving Social and Attitudinal Structures in Western Countries. Cambridge: Cambridge University Press.

Green-Pedersen, C. (2007) 'The Growing Importance of Issue Competition: The Changing Nature of Party Competition in Western Europe', Political Studies, 55 (3), 607-28.

Groseclose, T. and McCarty, N. (2001) 'The Politics of Blame: Bargaining before an Audience', American Journal of Political Science, 45 (1), 100-19.

Hobolt, S. B. and Klemmensen, R. (2005) 'Responsive Government? Public Opinion and Government Policy Preferences in Britain and Denmark', Political Studies, 53 (2), 379-402.

Hobolt, S. B. and Klemmensen, R. (2008) 'Government Responsiveness and Political Competition in Comparative Perspective', Comparative Political Studies, 41 (3), 309-37.

Hood, C. (2006) 'Gaming in Targetworld: The Targets Approach to Managing British Public Services', Public Administration Review, 66 (4), 515-21.

Jennings, W. and John, P. (2009) 'The Dynamics of Political Attention: Public Opinion and the Queen's Speech in the United Kingdom', American Journal of Political Science, 53 (4), 838-54.

Jennings, W., Bevan, S., Timmermans, A., Breeman, G., Brouard, S., Chaques, L., Green-Pedersen, C., John, P., Mortensen, P. B. and Palau, A. (2009) 'Effects of the Core Functions of Government on the Diversity of Executive Agendas'. Paper presented to the Annual Conference of the Comparative Agendas Project, The Hague, the Netherlands, July. 
John, P. and Jennings, W. (2010) 'Punctuations and Turning Points in British Politics: The Policy Agenda of the Queen's Speech, 1940-2005', British Journal of Political Science, 40 (3), 561-86.

Jones, B. D. and Baumgartner, F. R. (2005) The Politics of Attention: How Government Prioritizes Problems. Chicago IL: University of Chicago Press.

Kernell, S. (1997) Going Public: New Strategies of Presidential Leadership. Washington DC: CQ Press.

Kingdon, J. (1984) Agendas, Alternatives and Public Policies. New York: HarperCollins.

Klingemann, H.-D., Hofferbert, R. I. and Budge, I. (1994) Parties, Policies and Democracy. Boulder CO: Westview Press.

McCombs, M. E. and Shaw, D. L. (1972) 'The Agenda-Setting Function of Mass Media', Public Opinion Quarterly, 36 (2), $176-87$.

McDonald, M. D. and Budge, I. (2005) Elections, Parties, Democracy. Oxford: Oxford University Press.

Namenwirth, J. Z. and Weber, R. P. (1987) Dynamics of Culture. London: Allen \& Unwin.

North, D. C. and Weingast, B. R. (1989) 'Constitutions and Commitment: Evolution of Institutions Governing Public Choice in 17th Century England', Journal of Economic History, XLIX (4), 803.

Petrocik, J. R. (1996) 'Issue Ownership in Presidential Elections, with a 1980 Case Study', American Journal of Political Science, 40 (3), 825-50.

Rhodes, R. A. W. (1994) 'The Hollowing Out of the State', Political Quarterly, 65 (2), 138-51.

Rhodes, R. A. W. (1997) Understanding Governance. Buckingham: Open University Press.

Richardson, J. and Jordan, G. (1979) Governing under Pressure: The Policy Process in a Post-Parliamentary Democracy. Oxford: Martin Robertson.

Rose, R. (1980) Do Parties Make a Difference? London: Macmillan.

Rose, R. and Davies, P. (1994) Inheritance in Public Policy. New Haven CT: Yale University Press.

Rudalevige, A. (2002) Managing the President's Program: Presidential Leadership and Legislative Policy Formation. Princeton, NJ: Princeton University Press.

Schattschneider, E. E. (1960) The Semi-Sovereign People. New York: Holt, Rinehart and Winston.

Shannon, C. E. (1948) 'A Mathematical Theory of Communication', Bell System Technical Journal, 27 (July), 379-423, 27 (October), 623-56.

Strøm, K. (2000) 'Delegation and Accountability in Parliamentary Democracies', European Journal of Political Research, 37 (May), 261-89.

Strøm, K. (2001) 'Parliamentary Democracy and Delegation', in K. Strøm, W. C. Müller and T. Bergman (eds), Delegation and Accountability in Parliamentary Democracies. Oxford: Oxford University Press, pp. 55-106.

True, J. L., Jones, B. D. and Baumgartner, F. R. (2007) 'Punctuated-Equilibrium Theory: Explaining Stability and Change in American Policymaking', in P. Sabatier (ed.), Theories of the Policy Process, second edition. Boulder CO: Westview Press.

Volkens, A. (2002) 'Manifesto Coding Instructions'. Discussion Paper FS III 02-201. Berlin: WZB. 